\title{
Functions of DPLIY motif and helix 8 of human melanocortin-3 receptor
}

\author{
Zhao Yang', Zhi-Li Huang ${ }^{1,2}$ and Ya-Xiong Tao' \\ ${ }^{1}$ Department of Anatomy, Physiology and Pharmacology, College of Veterinary Medicine, Auburn University, \\ 212 Greene Hall, Auburn, Alabama 36849, USA \\ ${ }^{2}$ School of Applied Chemistry and Biological Technology, Shenzhen Polytechnic, Shenzhen 518055, China
}

Correspondence

should be addressed

to $\mathrm{Y}-\mathrm{X}$ Tao

Email

taoyaxi@auburn.edu

\begin{abstract}
The melanocortin-3 receptor (MC3R) is a member of the family A G protein-coupled receptors (GPCRs). The MC3R remains the most enigmatic of the melanocortin receptors with regard to its physiological functions, especially its role in energy homeostasis. The N/DPxxY motif and the eighth helix (helix 8) in the carboxyl terminus of GPCRs have been identified to be important for receptor expression, ligand binding, signal transduction and internalization. To gain a better understanding of the structure-function relationship of MC3R, we performed a systematic study of all 20 residues in this domain using alanine-scanning mutagenesis. We showed that although all mutants were expressed normally on the cell surface, eleven residues were important for ligand binding and one was indispensable for downstream CAMP generation. F347A showed constitutive activity in CAMP signaling while all the other mutants had normal basal activities. We studied the signaling capacity of nine mutants in the ERK1/2 signaling pathway. All of these mutants showed normal basal ERK $1 / 2$ phosphorylation levels. The pERK $1 / 2$ levels of six binding- or signaling-defective mutants were enhanced upon agonist stimulation. The unbalanced CAMP and PERK $1 / 2$ signaling pathways suggested the existence of biased signaling in MC3R mutants. In summary, we showed that the DPLIY motif and helix 8 was important for MC3R activation and signal transduction. Our data led to a better understanding of the structure-function relationship of MC3R.
\end{abstract}
Key Words
- melanocortin-3 receptor
- G protein-coupled receptor
- constitutively active mutant
- biased signaling
- energy homeostasis

Journal of Molecular

Endocrinology

(2015) 55, 107-117

\section{Introduction}

The melanocortin-3 receptor (MC3R), a member of family A G protein-coupled receptors (GPCRs) (Gantz et al. 1993, Roselli-Rehfuss et al. 1993), has received increasing attention with regard to its multiple physiological functions (reviewed in Renquist et al. (2011)). The MC3R is primarily expressed in hypothalamus, especially in the arcuate nucleus, the ventromedial nucleus and the posterior hypothalamic region (Jegou et al. 2000). It is also expressed in several peripheral tissues, including the placenta, gut, heart, kidney, and peritoneal macrophages (Gantz et al. 1993, Chhajlani 1996, Getting et al. 2003,
Ni et al. 2006). Based on its wide distribution, the MC3R has been shown to be involved in regulating cardiovascular function (Versteeg et al. 1998, Mioni et al. 2003), natriuresis (Ni et al. 2006, Chandramohan et al. 2009), and inflammation (Catania et al. 2004, Getting et al. 2006, Getting et al. 2008).

The MC3R, together with MC4R, another member of melanocortin receptor family expressed in the central nervous system, has been considered as a potential regulator of energy homeostasis. But unlike the MC4R, which is a well-known mediator of leptin action

Published by Bioscientifica Ltd 
(Cone 1999) and is crucial for both food intake and energy expenditure regulation (Huszar et al. 1997, reviewed in Tao (2010a)), the MC3R is shown to be primarily involved in affecting feed efficiency rather than mediating food intake or energy expenditure (Butler et al. 2000, Chen et al. 2000). The MC4R plays an undisputed role in human obesity pathogenesis since mutations in $M C 4 R$ have been characterized as the most common monogenic form of obesity in human (Farooqi et al. 2003, Tao 2009, Hinney et al. 2013). However, the role of $M C 3 R$ in human obesity pathogenesis is more controversial (reviewed in Tao $(2010 b)$ ), although some MC3R mutations (such as I183N and I335S) have been recognized as possible genetic contributors for morbid obesity (Lee et al. 2002, 2007, Rached et al. 2004, Tao \& Segaloff 2004, Tao 2007, Mencarelli et al. 2008, Yang \& Tao 2012, Yang et al. 2015).

The MC3R is a typical GPCR consisting of seven transmembrane helices (TMs) with an extracellular $\mathrm{N}$-terminus and intracellular C-terminus. The currently known crystal structures of typical family A GPCRs reveal the existence of an eighth helix (helix 8) (Mustafi \& Palczewski 2009, Rosenbaum et al. 2009), which initiates just after the highly conserved N/DPxxY motif (Asn/ Asp-Pro-Xaa-Xaa-Tyr) in TM7 (DPLIY in the MC3R) and terminates either with anchorage into the plasma membrane by acylation of cysteine residues, or with kinks produced by proline residues. There are only a few GPCRs that do not have this helix in the crystal structures (Zhang et al. 2015). To date, the functional importance of the N/DPxxY motif and helix 8 has been emerging in GPCR expression, conformational switch upon GPCR activation, G protein coupling, and GPCR internalization (Wess et al. 1993, Barak et al. 1995, Prioleau et al. 2002, Fritze et al. 2003, Tetsuka etal. 2004, Delos Santos etal. 2006, Swift etal. 2006).

However, no systematic study of the DPLIY motif and helix 8 of MC3R has been reported. In order to gain a better understanding of the structure-function relationship of the human MC3R (hMC3R), we investigated the function of each residue in these two domains of the receptor using alanine-scanning mutagenesis. We generated 20 mutants and studied the cell surface expression, ligand binding and signaling properties of the mutant receptors. MC3R activation has also been reported to stimulate ERK1/2 phosphorylation (Chai et al. 2007, Begriche et al. 2012) (one report suggested that the MC3R does not activate ERK1/2 (Daniels et al. 2003)). However, we and others recently reported biased signaling in the MC3R (Huang \& Tao 2014, Montero-Melendez et al. 2015, Yang et al. 2015), the ERK1/2 signaling pathway of the hMC3R was also investigated.

\section{Materials and methods}

\section{Materials}

$\left[\mathrm{Nle}^{4}, \quad\right.$ D-Phe $\left.{ }^{7}\right]-\alpha$-melanocyte stimulation hormone (NDP-MSH) was purchased from Bachem (King of Prussia, PA, USA). ${ }^{125}$ I-NDP-MSH was iodinated as previously described (Mo et al. 2012). Radiolabeled cAMP was iodinated in our lab with chloramine T method (Tao et al. 2010).

\section{Site-directed mutagenesis}

The WT hMC3R tagged at the N-terminus with $3 \times \mathrm{HA}$ tag was obtained from Missouri S\&T cDNA Resource Center (http://www.cDNA.org). Mutations were generated from the WT receptor by QuikChange site-directed mutagenesis kit (Stratagene, La Jolla, CA, USA) using the primers listed in Table 1. Plasmid DNAs were purified by IsoPure Maxi Prep Kit (Denville Scientific, Metuchen, NJ, USA). DNA sequencing was performed by the DNA Sequencing Facility of University of Chicago Cancer Research Center (Chicago, IL, USA) to confirm the presence of intended mutations and nonexistence of unintended mutations.

\section{Cell culture and DNA transfection}

Human embryonic kidney (HEK) 293T cells, purchased from American Type Culture Collection (Manassas, VA,

Table 1 Forward primer sequences used for site-directed mutagenesis studies of hMC3R. The mutated codons are underlined

\begin{tabular}{|c|c|}
\hline Constructs & Primer sequences \\
\hline D332A & CAACTCCGTCATCGCCCCACTCATCTACG \\
\hline P333A & CTCCGTCATCGACGCA CTCATCTACGC \\
\hline L334A & CTCCGTCATCGACCCAGCCATCTACGCTTTCCGG \\
\hline I335A & CATCGACCCACTCGCC $\overline{T A C G C T T T C C ~}$ \\
\hline Y336A & CATCGACCCACTCDATCGCCGCTTTCCGGAGCCTG \\
\hline A337G & CCACTCATCTACGGTTTCCGGAGCCTG \\
\hline F338A & СCCACTCATCTAC̄CGTGCCCGGAGCCTGGAATTG \\
\hline R339A & CTCATCTACGCTTTCGCGAGCCTGGAATTGCG \\
\hline S340A & CATCTACGCTTTCCGGGCCCTGGAATTGCGCAAC \\
\hline L341A & CTACGCTTTCCGGAGCGCGGAATTGCGCAACACC \\
\hline E342A & CGCTTTCCGGAGCCTGGCATTGCGCAACACCTTTAG \\
\hline L343A & 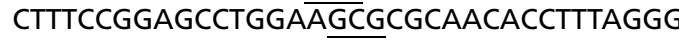 \\
\hline R344A & CGGAGCCTGGAATTGGCCAACACCTTTAGGGAG \\
\hline N345A & 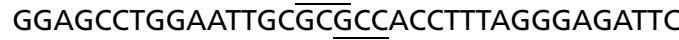 \\
\hline T346A & CTGGAATTGCGCAACGCCTTTAGGGAGATTC \\
\hline F347A & 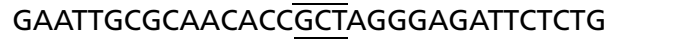 \\
\hline R348A & GCGCAACACCTTTGCGGAGATTCTCTGTG \\
\hline E349A & CAACACCTTTAGGGCGATTCTCTGTGGC \\
\hline I350A & CACCTTTAGGGAGGCTCTCTGTGGCTGC \\
\hline L351A & CACCTTTAGGGAG $\overline{A T T G C C T G T G G C T G C A A C G G C ~}$ \\
\hline
\end{tabular}

Published by Bioscientifica Ltd 
USA), were cultured in DMEM containing 10\% newborn calf serum. The cells were plated into six-well clusters (or $100 \mathrm{~mm}$ dishes for western blot) pre-coated with $0.1 \%$ gelatin and transfected with purified plasmids at 50-70\% confluency using calcium phosphate precipitation method (Chen \& Okayama 1987). Flow cytometry assay, ligand binding, and signaling studies were performed approximately $48 \mathrm{~h}$ after transient transfection.

\section{Quantification of MC3R cell surface expression by flow cytometry}

Forty-eight hours after transfection, HEK 293T cells were washed with filtered PBS for immunohistochemistry (PBS-IH) (Tao \& Segaloff 2003) and fixed by $4 \%$ paraformaldehyde in PBS-IH for $30 \mathrm{~min}$. After blocking with PBS-IH containing 5\% BSA for $1 \mathrm{~h}$, the cells were then incubated with the primary antibody anti-HA.11 (Covance, Princeton, NJ, USA), which was diluted 1:100 in PBS-IH containing 5\% BSA, for another $1 \mathrm{~h}$. The cells were washed once with $0.5 \%$ BSA in PBS-IH and then incubated with the secondary antibody Alexa Fluor 488-labeled goat antimouse IgG (Invitrogen) for $1 \mathrm{~h}$. The cell surface expression of WT and mutant hMC3Rs was analyzed by Accuri flow cytometer (Accuri Cytometers, Ann Arbor, MI, USA). The expression levels of the mutant hMC3Rs were calculated as the percentage of WT hMC3R expression using the formula: (mutant - pcDNA3.1)/(WT - pcDNA3.1) $\times 100 \%$, where the pcDNA3.1 were used as control for background staining (Wang et al. 2008, Yang \& Tao 2012).

\section{Ligand binding assays}

Fourty-eight hours after transfection, HEK 293T cells were washed twice with warm Waymouth's MB752/1 media (Sigma-Aldrich) containing $1 \mathrm{mg} / \mathrm{ml}$ BSA (Waymouth/ BSA). The cells were incubated with Waymouth/BSA containing $100000 \mathrm{cpm}$ of ${ }^{125}$ I-NDP-MSH with or without different concentrations of unlabeled NDP-MSH (from $10^{-12}$ to $10^{-6} \mathrm{M}$ ) at $37^{\circ} \mathrm{C}$ for $1 \mathrm{~h}$. The reaction was terminated by washing twice with cold Hank's balanced salt solution on ice. The cells were lysed by $100 \mu \mathrm{l} 0.5 \mathrm{~N}$ $\mathrm{NaOH}$, collected using cotton swabs, and detected in gamma counter.

\section{Ligand stimulated CAMP production}

Forty-eight hours after transfection, HEK 293T cells were washed twice with warm Waymouth/BSA and then incubated with fresh Waymouth/BSA containing $0.5 \mathrm{mM}$ isobutylmethylxanthine (Sigma-Aldrich) at $37^{\circ} \mathrm{C}$ for $15 \mathrm{~min}$. Then different concentrations of NDP-MSH were added into each well to make the final volume $1 \mathrm{ml}$ and final concentration ranging from $10^{-12}$ to $10^{-6} \mathrm{M}$. After $1 \mathrm{~h}$ incubation at $37^{\circ} \mathrm{C}$, the reaction was terminated on ice and the intracellular cAMP was extracted by adding $0.5 \mathrm{~N}$ perchloric acid containing $180 \mu \mathrm{g} / \mathrm{ml}$ theophylline and $0.72 \mathrm{M} \mathrm{KOH} / 0.6 \mathrm{M} \mathrm{KHCO}_{3}$ into each well. Cyclic AMP concentrations were determined by radioimmunoassay as described in detail before (Tao et al. 2010, Yang \& Tao 2012).

\section{Protein preparation and western blot}

Twenty-four hours after transfection, HEK 293T cells were starved in Waymouth/BSA at $37^{\circ} \mathrm{C}$ for $24 \mathrm{~h}$. After being treated with or without $1 \mu \mathrm{M}$ NDP-MSH for $5 \mathrm{~min}$ at $37^{\circ} \mathrm{C}$ on the second day, the cells were transferred directly to ice, washed twice using cold $0 \mathrm{G}(150 \mathrm{mM} \mathrm{NaCl}$ and $20 \mathrm{mM}$ Hepes, $\mathrm{pH} 7.4)$, and then scraped into lysis buffer (0G containing 0.5\% NP-40, $2 \mathrm{mM}$ EDTA, $1 \mathrm{mM} \mathrm{Na}_{3} \mathrm{VO}_{4}$, and $1 \mathrm{mM} \mathrm{NaF})$. Total protein concentrations were determined by Bradford protein assay and $35 \mu \mathrm{g}$ protein samples were separated on $10 \%$ SDS-PAGE gel, and then blotted onto PVDF membranes. After blocking in $10 \%$ nonfat dry milk (containing $0.2 \%$ Tween-20) for at least $4 \mathrm{~h}$ at room temperature, the membranes were then immunoblotted with rabbit anti-pERK1/2 antibody (Cell Signaling, Beverly, MA, USA) 1:2000 and mouse anti- $\beta$-tubulin antibody (Developmental Studies Hybridoma Bank, University of Iowa, Iowa City, IA, USA) 1:5000 diluted in Tris-buffered saline containing Tween 20 (TBST) with 5\% BSA overnight at $4{ }^{\circ} \mathrm{C}$. The membranes were then probed with HRPconjugated secondary antibody, donkey anti-rabbit (Jackson ImmunoResearch, West Grove, PA, USA) 1:1500 and donkey anti-mouse IgG (Jackson ImmunoResearch) 1:5000 diluted in 10\% nonfat dry milk for $2 \mathrm{~h}$ at room temperature. Specific bands were visualized using ECL reagent (Thermo Scientific, Rockford, IL, USA) and then analyzed using Image J Software (NIH, Bethesda, MD, USA).

\section{Statistical analysis}

GraphPad Prism 4.0 Software (San Diego, CA, USA) was used to calculate the ligand binding parameters including maximal binding $\left(B_{\max }\right)$ and $\mathrm{IC}_{50}$ as well as the cAMP signaling parameters including maximal response $\left(R_{\max }\right)$ and $\mathrm{EC}_{50}$. The significance of differences in binding and signaling parameters, receptor cell surface expression levels, and pERK1/2 activities between the WT and mutant

Published by Bioscientifica Ltd. 
hMC3Rs were determined by Student's t-test using GraphPad Prism 4.0.

\section{Results}

NDP-MSH, an analog of endogenous $\alpha$-MSH (Sawyer $e t$ al. 1980), has been shown to be a superpotent agonist for MC3R and was used in the present study. To determine the function of each residue of the DPLIY motif and helix 8 of MC3R, we generated 20 mutants using alanine-scanning mutagenesis (Table 1, Fig. 1). Since the mutant I335A has been studied previously (Tao 2007), its ligand binding and signaling property studies are not included herein.

\section{Cell surface expression of the WT and mutant hMC3Rs}

Retention of the mutant receptors in the endoplasmic reticulum (ER) resulting from failing to pass the quality control system has been recognized as the major defect of inactivating mutations in numerous GPCRs (reviewed in Tao (2006) and Tao \& Conn (2014)). To investigate the cell surface expression of the mutants, flow cytometry was performed. As shown in Fig. 2, all mutants were expressed normally on the cell surface and no significant differences were observed between the WT hMC3R and the mutants. The data for I335A here were in agreement with previous results using confocal microscopy (Tao 2007). To confirm the results, we further tested the HA-tagged I335S and D158E. Our data were consistent with previous reports that I335S is intracellularly retained (with only $\sim 5 \%$ WT hMC3R expression at the cell surface) while D158E is partially retained with decreased cell surface expression compared to the WT hMC3R (Fig. 2) (Tao 2007, Wang et al. 2008).

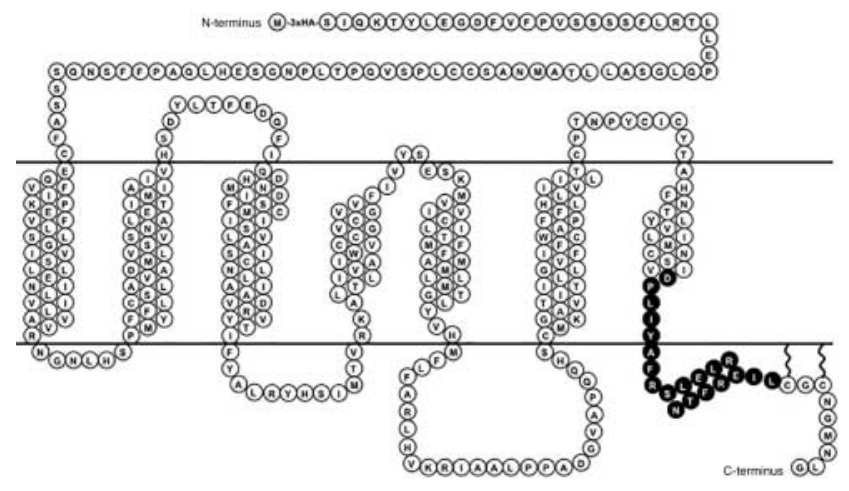

\section{Figure 1}

Schematic model of the hMC3R with the 20 residues characterized in the present study highlighted.

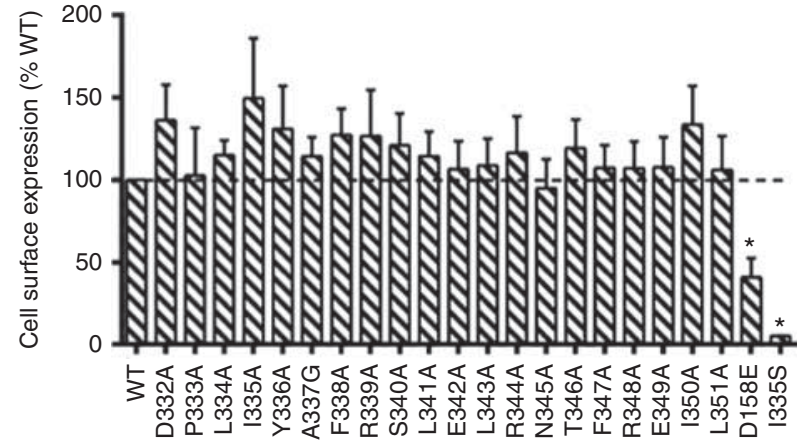

Figure 2

Cell surface expression of the WT and mutant hMC3Rs by flow cytometry. The results are expressed as \% of cell surface expression level of WT hMC3R after correction of the nonspecific staining in cells transiently transfected with the empty vector as described in Materials and methods. Values are mean \pm s.E.M. of at least three independent experiments. * indicates significantly different from WT hMC3R $(P<0.05)$.

\section{Ligand binding of the WT and mutant hMC3Rs}

To compete with different concentrations of unlabeled NDP-MSH, ${ }^{125}$ I-NDP-MSH was used as the radioligand in the binding assay. The result showed that P333A, L343A, and $\mathrm{R} 344 \mathrm{~A}$ had no detectable binding. Nine mutants (L334A, Y336A, S340A, E342A, F347A, R348A, E349A, I350A, and L351A) showed decreased $\mathrm{IC}_{50}$ while only one mutant, L341, had increased $\mathrm{IC}_{50}$. There were no significant differences between the $\mathrm{IC}_{50} \mathrm{~s}$ of all the other mutants and that of the WT hMC3R (Table 2, Fig. 3).

As shown in Fig. 4, nine mutants (D332A, L344A, Y336A, S340A, E342A, F347A, R348A, I350A, and L351A) had significantly decreased maximal binding compared with WT hMC3R while one mutant (F338A) showed significantly, although very slightly, increased maximal binding. All the other mutants had similar maximal binding as the WT hMC3R.

\section{Signaling properties of the WT and mutant hMC3Rs}

Whether the hMC3R variants could respond to NDP-MSH stimulation with enhanced cAMP generation was then investigated. As expected, NDP-MSH could stimulate dosedependent increase of intracellular cAMP in HEK293T cells transfected with WT hMC3R. As shown in Table 2, two mutants (Y336A and E342A), in addition to three bindingdefective mutants (P333A, L343A, and R344A), had no measurable signaling. F338A and R339A showed increased $\mathrm{EC}_{50}$ while F347A displayed reduced $\mathrm{EC}_{50}$. No significant differences were observed between the $\mathrm{EC}_{50} \mathrm{~s}$ of all the other mutants and that of the WT hMC3R.

Published by Bioscientifica Ltd. 
Table 2 The ligand binding and signaling properties of WT and mutant hMC3Rs. Values are expressed as the mean \pm S.E.M. of at least four independent experiments. The $R_{\max }$ of WT hMC3R was $2386.00 \pm 239.95 \mathrm{pmol} / 10^{6}$ cells upon NDP-MSH stimulation

\begin{tabular}{l}
\hline hMC3R \\
\hline WT \\
D332A \\
P333A \\
L334A \\
Y336A \\
A337G \\
F338A \\
R339A \\
S340A \\
L341A \\
E342A \\
L343A \\
R344A \\
N345A \\
T346A \\
F347A \\
R348A \\
E349A \\
I350A \\
L351A
\end{tabular}

\begin{tabular}{c}
\hline NDP-MSH binding \\
\hline $\mathrm{I}_{50}(\mathrm{nM})$ \\
\hline $2.63 \pm 0.27$ \\
$1.59 \pm 0.27$ \\
$\mathrm{~N} / \mathrm{A}^{\mathrm{a}}$ \\
$1.09 \pm 0.07^{\mathrm{b}}$ \\
$0.79 \pm 0.10^{\mathrm{b}}$ \\
$2.32 \pm 0.42$ \\
$3.17 \pm 0.79$ \\
$2.38 \pm 0.28$ \\
$0.84 \pm 0.12^{\mathrm{b}}$ \\
$4.81 \pm 1.13^{\mathrm{c}}$ \\
$0.58 \pm 0.02^{\mathrm{d}}$ \\
$\mathrm{N} / \mathrm{A}^{\mathrm{a}}$ \\
$\mathrm{N} / \mathrm{A}^{\mathrm{a}}$ \\
$1.89 \pm 0.17$ \\
$2.08 \pm 0.18$ \\
$1.09 \pm 0.19^{\mathrm{b}}$ \\
$0.91 \pm 0.04^{\mathrm{b}}$ \\
$1.21 \pm 0.18^{\mathrm{c}}$ \\
$0.61 \pm 0.07^{\mathrm{b}}$ \\
$0.64 \pm 0.03^{\mathrm{b}}$
\end{tabular}

\begin{tabular}{cc}
\multicolumn{2}{c}{ NDP-MSH-stimulated CAMP } \\
\hline $\mathrm{EC}_{50}(\mathrm{nM})$ & $R_{\max }(100 \%)$ \\
\hline $0.47 \pm 0.05$ & 100 \\
$0.43 \pm 0.04$ & $98.50 \pm 18.45$ \\
$\mathrm{~N} / \mathrm{A}^{\mathrm{a}}$ & $\mathrm{N} / \mathrm{A}^{\mathrm{a}}$ \\
$0.39 \pm 0.10$ & $\mathrm{~N} \pm .50 \pm 12.12$ \\
$\mathrm{~N} / \mathrm{A}^{\mathrm{a}}$ & $\mathrm{N} / \mathrm{A}^{\mathrm{a}}$ \\
$0.57 \pm 0.17$ & $98.25 \pm 11.27$ \\
$0.90 \pm 0.24^{\mathrm{c}}$ & $94.75 \pm 15.58$ \\
$2.34 \pm 0.37^{\mathrm{d}}$ & $48.33 \pm 20.00^{\mathrm{c}}$ \\
$0.77 \pm 0.22$ & $52.29 \pm 13.18^{\mathrm{c}}$ \\
$0.50 \pm 0.07$ & $102.50 \pm 19.31$ \\
$\mathrm{~N} / \mathrm{A}^{\mathrm{a}}$ & $\mathrm{N} / \mathrm{A}^{\mathrm{a}}$ \\
$\mathrm{N} / \mathrm{A}^{\mathrm{a}}$ & $\mathrm{N} / \mathrm{A}^{\mathrm{a}}$ \\
$\mathrm{N} / \mathrm{A}^{\mathrm{a}}$ & $\mathrm{N} / \mathrm{A}^{\mathrm{a}}$ \\
$0.36 \pm 0.08$ & $107.00 \pm 12.13$ \\
$0.48 \pm 0.16$ & $91.80 \pm 8.89$ \\
$0.25 \pm 0.06^{\mathrm{c}}$ & $67.25 \pm 8.38^{\mathrm{c}}$ \\
$0.42 \pm 0.11$ & $53.40 \pm 5.62^{\mathrm{b}}$ \\
$0.47 \pm 0.16$ & $103.00 \pm 23.34$ \\
$0.33 \pm 0.07$ & $15.75 \pm 1.55^{\mathrm{d}}$ \\
$0.32 \pm 0.10$ & $17.50 \pm 2.02^{\mathrm{d}}$
\end{tabular}

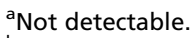

bSignificantly different from WT hMC3R, $P<0.01$.

'Significantly different from WT hMC3R, $P<0.05$.

${ }^{\mathrm{d}}$ Significantly different from WT hMC3R, $P<0.001$.

Our data of maximal response in Fig. 5 also showed that six mutants (R339A, S340A, F347A, R348A, I350A, and L351A) had significantly decreased maximal response compared with WT hMC3R. All the other mutants had apparent normal signaling.

\section{Constitutive activity of hMC3Rs}

Unlike the human MC4R, which has been previously shown to be constitutively active (Nijenhuis et al. 2001, Tao 2014), the hMC3R has been recognized with little or no constitutive activity (Tao 2007). In the present study, the constitutive activities of the 19 mutants of hMC3R (I335A not included) were analyzed. We demonstrated that the F347A had significantly increased basal activity compared with the WT hMC3R. As shown in Fig. 6A, the nearly 4.6 times elevation of basal activity demonstrated that the F347A was a constitutively active mutant, consistent with our previous report (Tao et al. 2010). All the other mutants had similar basal activities compared with that of the WT hMC3R. The dose-response curve in Fig. 6B highlights that F347A, although constitutively active, had reduced maximal response compared with the WT hMC3R.

\section{ERK1/2 signaling of the WT and mutant hMC3Rs}

To further investigate the ERK1/2 signaling pathway, especially the newly-identified biased signaling of hMC3R, the WT hMC3R together with nine mutants, including one constitutively active mutant (F347A) and eight binding- or signaling-defective mutants (P333A, I335A, Y336A, E342A, L343A, R344A, I350A, and L351A) which led to $<20 \%$ the WT receptor cAMP production, were studied using western blots. Empty vector pcDNA3.1 and WT hMC3R without the $3 \times$ HA tag were also studied, excluding non-specific stimulation.

Our results showed that the basal pERK1/2 levels in cells transfected with either WT MC3Rs (with or without $3 \times$ HA-tag) were similar to that of cells transfected with the empty vector (Fig. 7B). Upon $1 \mu \mathrm{M}$ NDP-MSH stimulation, WT MC3Rs showed significant ERK1/2 phosphorylation but no ERK1/2 activation was detected in cells transfected with an empty vector. There was no significant difference between the pERK1/2 levels of HA-tagged and non-tagged WT MC3Rs (Fig. 7C).

The constitutive activities of WT and mutant hMC3Rs in activating ERK1/2 were studied. Our results showed that all the mutants, including the F347A that was shown to be

Published by Bioscientifica Ltd 

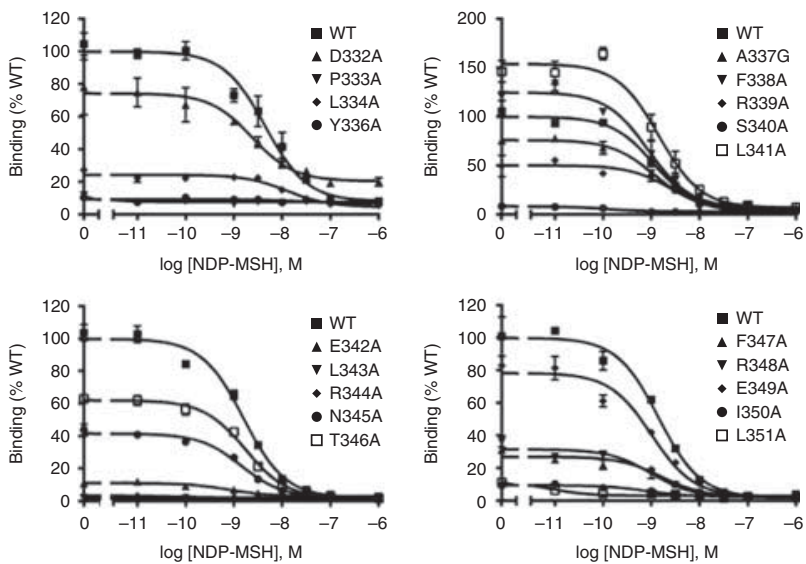

Figure 3

Ligand binding properties of the WT and mutant hMC3Rs with NDP-MSH as the ligand. HEK293T cells were transiently transfected with WT and mutant constructs, and the binding properties were measured $48 \mathrm{~h}$ later by displacing the binding of ${ }^{125} \mathrm{I}$-NDP-MSH using different concentrations of unlabeled NDP-MSH as described in Materials and methods. Data are expressed as $\%$ of WT binding \pm range from duplicate measurements within one experiment. All experiments were performed at least three times independently.

constitutively active in cAMP pathway, had similar basal pERK1/2 levels as the WT hMC3R (Fig. 7D).

We then investigated the pERK1/2 levels of WT and mutant hMC3Rs after $1 \mu \mathrm{M}$ NDP-MSH stimulation. As expected, the ERK1/2 phosphorylation was significantly enhanced in HEK 293T cells transfected with WT hMC3R. P333A and L343A did not respond to NDP-MSH stimulation with ERK1/2 activation while all other mutants had significantly increased pERK1/2 levels compared to the corresponding basal activity upon $1 \mu \mathrm{M}$ NDP-MSH stimulation (Fig. 7E).

\section{Discussion}

Although several physiological functions of the MC3R have now been described, it remains the most enigmatic member of the melanocortin receptor family. The recent identification of an additional helix 8, linking the TM7 and the C-terminus of GPCRs, has also aroused great interest. Analysis of the role of helix 8 in both family A and B GPCRs confirmed its importance in receptor expression, ligand binding, signal transduction and internalization (Ernst et al. 2000, Marin et al. 2000, Tetsuka et al. 2004, Faussner et al. 2005, Kuwasako et al. 2011). In the present study, we performed a detailed study of the 20 residues in helix 8 and the DPLIY motif of hMC3R using the classical method of site-directed alanine-scanning mutagenesis (Cunningham \& Wells 1989).

The flow cytometric analysis demonstrated that all mutants were expressed normally on the cell surface. Receptor retention or mislocalization, which has previously been described as the major defect for human disease caused by GPCR mutations (Tao 2006, Tao \& Conn 2014), was not observed in the present study. Similarly, in our studies on the second and third intracellular loops, we also showed that the alanine mutants are expressed normally at the cell surface (Wang \& Tao 2013, Huang \& Tao 2014).

Ligand binding studies revealed that 11 residues (P333, L334, Y336, S340, E342, L343, R344, F347, R348, I350 and L351) were important for NDP-MSH binding. Although it is uncommon that residues important for ligand binding are located in the cytoplasmic side of receptor, observations have been reported previously in MC3R (Huang \& Tao 2014) as well as other GPCRs, such as the gonadotropin-releasing hormone receptor ( $\mathrm{Lu}$ et al. 2005), angiotensin II type 2 receptor (Moore et al. 2002), and V2 vasopressin receptor (Pan et al. 1994). These residues are not expected to directly participate in ligand binding. Rather they might indirectly participate in ligand-receptor interaction through intramolecular interactions and conformational changes (Kobilka \& Deupi 2007, Rovati et al. 2007).

The highly conserved DPLIY motif is one of the two crucial motifs (the other one is D/ERY motif in TM3) for receptor stabilization and activation (Park et al. 2008). $\mathrm{P}^{7.50}$ (the superscript number represents BallesterosWeinstein numbering (Ballesteros \& Weinstein 1995)) has been regarded as critical in inducing a structurally

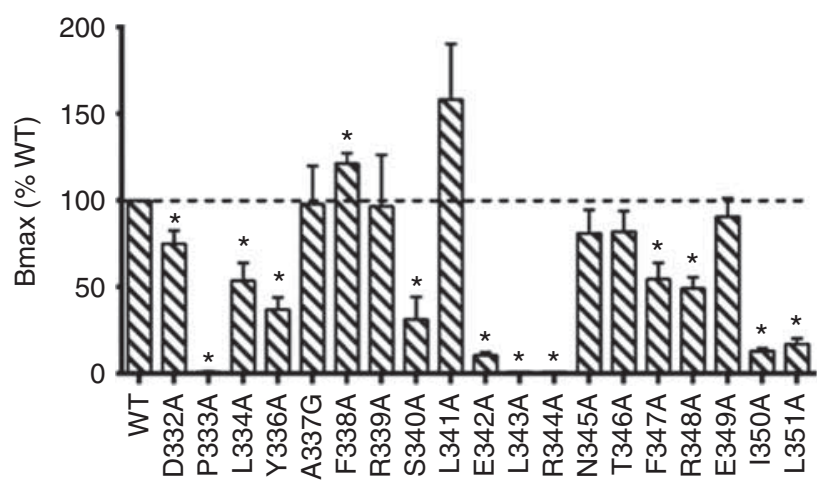

\section{Figure 4}

Total specific binding of WT and mutant hMC3Rs with NDP-MSH as the ligand. Data are mean \pm s.E.M. of at least three independent experiments. * indicates significantly different from WT hMC3R $(P<0.05)$.

Published by Bioscientifica Ltd. 


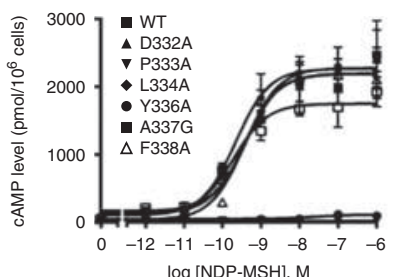

$\log [$ NDP-MSH], M
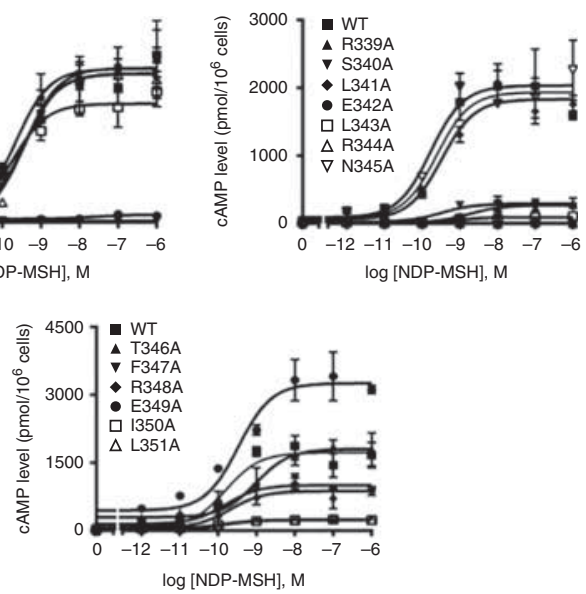

Figure 5

Signaling properties of the WT and mutant hMC3Rs with NDP-MSH as the ligand. HEK293T cells were transiently transfected with WT and mutant constructs, and intracellular CAMP levels were measured by RIA after stimulation with different concentrations of NDP-MSH as described in Materials and methods. Data are mean \pm s.E.M. from triplicate measurements within one experiment. All experiments were performed at least three times independently.

important helical break due to its distinctive cyclic structure of a side chain. Although $\mathrm{L}^{7.51}$ was not studied in detail before, its adjacent residue $\mathrm{I}^{7.52}$ has been recognized to be important in multiple aspects of MC3R function (Tao 2007). $\mathrm{L}^{7.51}$ might contribute to the supposed interaction between the $\mathrm{I}^{7.52}$ and hydrophobic residues in helix 8 to maintain the receptor conformation necessary for ligand binding. $\mathrm{Y}^{7.53}$ has been shown to be critical for receptor activation and signal transduction in many GPCRs, such as MC4R, gonadotropin-releasing receptor, and $5 \mathrm{HT}_{2 \mathrm{C}}$ receptor (Arora et al. 1996, Prioleau et al. 2002, Roth et al. 2009). The conformational change of tyrosine enables it to insert into the space previously occupied by TM6 and hinder its inward tilt to stabilize the active state (Scheerer et al. 2008). Mutations of the tyrosine residue in some other receptors result in either no ligand binding or defective signaling (Feng \& Song 2001). Our results here highlighted the importance of $\mathrm{Y}^{7.53}$ in hMC3R.

The $\mathrm{D} / \mathrm{E}(\mathrm{x})_{7} \mathrm{LL}$ motif, composed of a highly conserved di-leucine sequence with an upstream acidic residue, has been shown to be present in the C-terminus of several GPCRs such as $\alpha_{1^{-}}, \alpha_{2}$-adrenergic receptors and the dopamine receptor (Schulein et al. 1998). The corresponding residue of glutamate (E335 $5^{7.63}$ ) in the $\mathrm{V}_{2}$ vasopressin receptor was reported as crucial for establishing a transport-competent folding state to support the escape of the receptor from the ER (Schulein et al. 1998). The di-leucine motif, which should be strictly defined as a dihydrophobic pair due to mainly consisting of leucine, isoleucine or valine, was shown to play an important role in cell surface targeting, receptor internalization and protein trafficking (Gabilondo et al. 1997, Ho \& MacKenzie 1999). The alanine mutation of di-leucine pair was reported to have no effect on ligand affinity in the $\beta_{2}$-adrenergic receptor (Gabilondo et al. 1997), whereas the same mutation of di-isoleucine was shown to impair NDP-MSH binding to MC4R (VanLeeuwen et al. 2003). Our data demonstrated that the maximal binding of $\mathrm{E} 342^{7.59} \mathrm{~A}, \mathrm{I} 350^{7.67} \mathrm{~A}$, and $\mathrm{L} 351^{7.68} \mathrm{~A}$ had decreased by 90 , 87 and $83 \%$ respectively, compared with WT hMC3R, although all the mutant receptors could be normally expressed on the cell surface.

The interaction between two highly conserved aromatic residues, tyrosine in the $\mathrm{D} / \mathrm{NPxxY}$ motif and phenylalanine in helix 8 , has been highlighted in several studies. However, the conserved phenylalanine in the melanocortin receptor family is substituted by a leucine
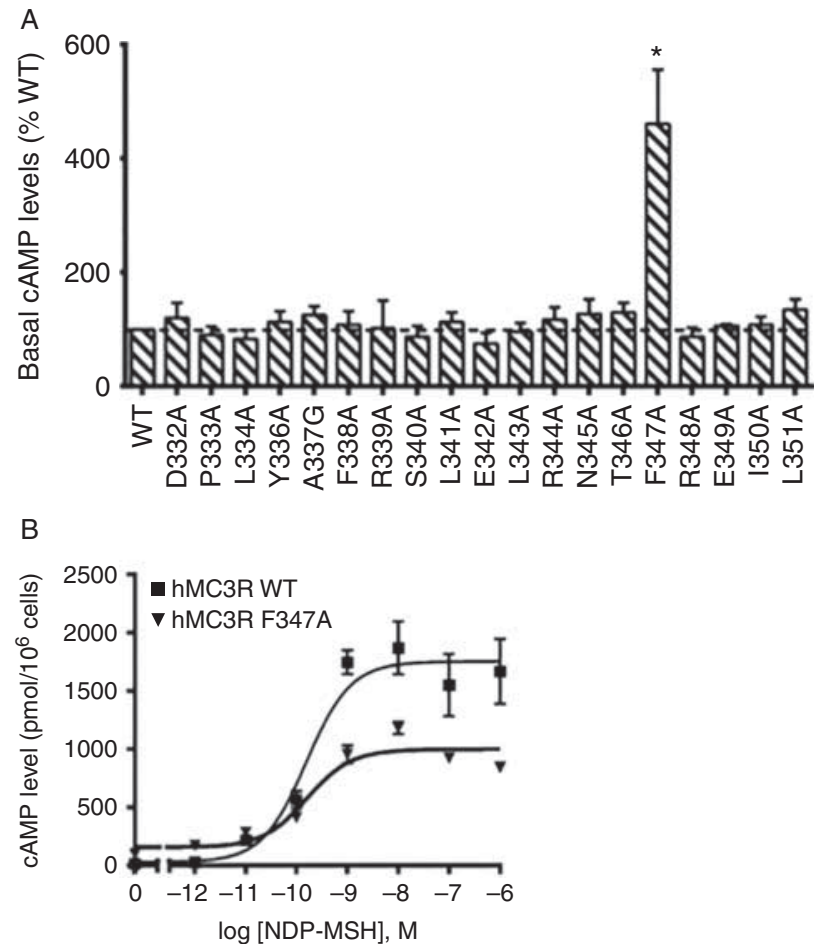

Figure 6

Basal activities of WT and mutant hMC3Rs. (A) HEK293T cells were transiently transfected with WT and mutant constructs, and intracellular CAMP levels were measured without ligand stimulation. Data are mean \pm S.E.M. of at least four independent experiments. The basal CAMP level of WT hMC3R was $25.79 \pm 2.69 \mathrm{pmol} / 10^{6}$ cells. * indicates significantly different from WT hMC3R $(P<0.05)$. (B) A representative dose-response curve of WT and F347A hMC3Rs. Similar results were obtained in at least three independent experiments.

Published by Bioscientifica Ltd. 

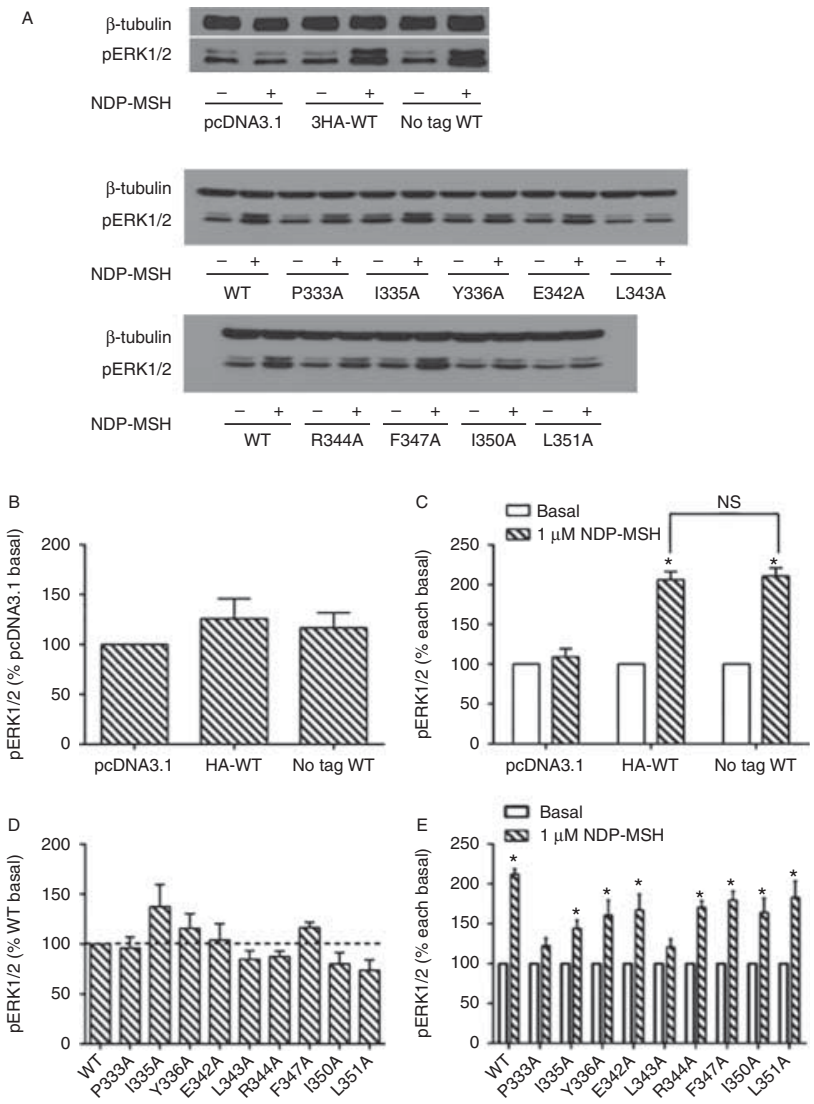

Figure 7

MAPK signaling of WT and mutant hMC3Rs. (A) HEK293T cells were transiently transfected with pcDNA3.1, WT (with or without HA tag) or mutant constructs, and $24 \mathrm{~h}$ later cells were starved overnight and then harvested after they were treated with or without $1 \mu \mathrm{M}$ NDP-MSH stimulation for $5 \mathrm{~min}$. Western blot analysis was performed using antibody against pERK $1 / 2$ and $\beta$-tubulin as control. (B) Basal pERK $1 / 2$ levels of cells transfected with pcDNA3.1 or WT hMC3Rs (with or without HA tag); data are mean \pm s.E.M. of three independent experiments. (C) Stimulated pERK $1 / 2$ levels in cells transfected with pCDNA3.1 or WT hMC3R (with or without HA tag) after $1 \mu \mathrm{M}$ NDP-MSH stimulation, expressed as a percentage of each basal pERK1/2 activity from three independent experiments. * indicates significantly different from corresponding basal level $(P<0.05)$ and NS means no statistical difference between HA-tagged and non-tagged WT hMC3R ( $P>0.05)$. (D) Data of the basal pERK1/2 of WT and mutant hMC3Rs are mean \pm S.E.M. of at least four independent experiments. (E) Data of the pERK1/2 levels of WT and mutant hMC3Rs after $1 \mu \mathrm{M}$ NDP-MSH stimulation are expressed as percentage of each basal pERK $1 / 2$ activity from at least four independent experiments. * indicates significantly different from corresponding basal activity $(P<0.05)$.

residue (L343 $3^{7.60}$ in hMC3R) and the function of replaced phenylalanine might be taken by another aromatic residue, $\mathrm{F} 347^{7.64}$. As previously discussed, the $\mathrm{I}^{7.52}$ in DPLIY motif of MC3R might interact with hydrophobic residues in helix 8 to maintain the receptor conformation. L343.60 is a preferable choice for taking part in the hydrophobic interaction since the mutant $\mathrm{L} 343^{7.60} \mathrm{~A}$ did not exhibit any binding or signaling in response to NDP-MSH stimulation in our study.

One residue, R339 $9^{7.56}$, was demonstrated to be crucial for normal receptor signaling. Alanine mutation of this arginine resulted in normal ligand binding but severely decreased signaling potency. Missense mutations of the corresponding residue of arginine in $\mathrm{hMC} 4 \mathrm{R}$, including $\mathrm{R} 305^{7.56} \mathrm{~S}, \mathrm{R} 305^{7.56} \mathrm{Q}$, and $\mathrm{R} 305^{7.56} \mathrm{~W}$, have been identified from obese patients (Tao 2009). R305 ${ }^{7.56} \mathrm{~S}$ and $\mathrm{R} 305^{7.56} \mathrm{Q}$ have been shown to have a partial cAMP response to $\alpha$-MSH stimulation (Stutzmann et al. 2008, Calton et al. 2009) and $\mathrm{R} 305^{7.56} \mathrm{~W}$ exhibits normal binding but severely impaired signaling in response to $\alpha-\mathrm{MSH}$ stimulation (Roubert et al. 2010), which is in agreement with our results of R339 ${ }^{7.56} \mathrm{~A}$ hMC3R.

The MC3R has been reported to activate the ERK1/2 signaling pathway (see Introduction). Unbalanced cAMP and ERK1/2 signaling was reported in some human MC4R mutants (Huang \& Tao 2012, Mo et al. 2012, He \& Tao 2014) (reviewed in Tao (2014)). In our recent study of the DRY motif and intracellular loop 2 of hMC3R, the presence of this biased signaling was also suggested (Huang \& Tao 2014). In the current study to test it further, the ERK1/2 phosphorylation levels of nine hMC3R mutants, including eight binding- or signaling-defective mutants (P333A, I335A, Y336A, E342A, L343A, R344A, I350A, and L351A) which led to $<20 \%$ cAMP production compared with WT hMC3R, and one constitutively active mutant (F347A) with enhanced basal cAMP activity, were investigated using western blots.

Non-specific effects were excluded in the present study by using the empty vector pcDNA3.1 and non-tagged WT hMC3R. The results indicated that there was no endogenous receptor in HEK293T cells responding to NDP-MSH stimulation and HA tag did not have any effect on MC3R activation of ERK1/2 (Fig. 7A, B and C). All nine mutants had similar basal pERK1/2 levels as the WT MC3R. Notably, F347A, which had increased basal cAMP level, did not show any increase in the basal pERK1/2 level compared with WT hMC3R. Upon $1 \mu \mathrm{M}$ NDP-MSH stimulation, two binding-defective mutants, P333A and L343A, did not activate ERK1/2. However, all the other tested mutants, especially I335A, Y336A, E342A, and R344A that had almost no cAMP response, had shown significant ERK1/2 activation. Two mutants with no detectable binding, I335A (Tao 2007) and R344A (present study), responded to NDP-MSH stimulation with increased pERK1/2 levels. Although it is uncommon, similar observations have been previously reported in other GPCRs, such as MC4R (Huang \& Tao 2012) and

Published by Bioscientifica Ltd 
gonadotropin-releasing hormone receptor (Bedecarrats et al. 2003). This might be due to a faster dissociation of the ligand from the MC3R mutants compared with the WT receptor making the binding difficult to detect, but ERK1/2 could still be activated by this transient binding (Huang \& Tao 2014). NDP-MSH was reported to induce ERK1/2 phosphorylation in HEK293 cells transfected with WT MC3R in a very fast and potent pattern, peaking at only 5 min with an $\mathrm{EC}_{50}$ of $3.3 \pm 1.5 \mathrm{nM}$ (Chai et al. 2007). These data suggest these mutants were biased receptors, supporting two recent studies on biased signaling at the MC3R (Montero-Melendez et al. 2015, Yang et al. 2015).

In summary, from the systematic study of the DPLIY motif and helix 8 of hMC3R, we have identified residues that were crucial for ligand binding and cAMP generation. One constitutively active mutant was identified and the existence of biased signaling was confirmed in MC3R mutants. The data obtained in our present research indicated that the highly conserved DPLIY motif and helix 8 play important roles in MC3R activation and signal transduction. Our result established a theoretical basis for the structure-functional relationship of MC3R and will be useful for further investigation of its physiological role in energy homeostasis.

\section{Declaration of interest}

The authors declare that there is no conflict of interest that could be perceived as prejudicing the impartiality of the research reported.

\section{Funding}

This study was supported by grants from the National Institutes of Health R15DK077213 and Animal Health and Disease Research Program of Auburn University College of Veterinary Medicine. $\mathrm{Z} Y$ was supported by a fellowship from China Scholarship Council of the People's Republic of China. Z-L H was supported by a fellowship from Shenzhen Polytechnic.

\section{Acknowledgements}

We thank Dr Shuxiu Wang for generating the mutant constructs and performing some of the preliminary experiments.

\section{References}

Arora KK, Cheng Z \& Catt KJ 1996 Dependence of agonist activation on an aromatic moiety in the DPLIY motif of the gonadotropin-releasing hormone receptor. Molecular Endocrinology 10 979-986. (doi:10.1210/ mend.10.8.8843414)

Ballesteros JA \& Weinstein H 1995 Integrated methods for the construction of three-dimensional models and computational probing of structure-function relations in $\mathrm{G}$ protein-coupled receptors. Methods in Neuroscience 25 366-428.
Barak LS, Menard L, Ferguson SS, Colapietro AM \& Caron MG 1995 The conserved seven-transmembrane sequence $\mathrm{NP}(\mathrm{X}) 2,3 \mathrm{Y}$ of the G-protein-coupled receptor superfamily regulates multiple properties of the $\beta 2$-adrenergic receptor. Biochemistry 34 15407-15414. (doi:10.1021/bi00047a003)

Bedecarrats GY, Linher KD, Janovick JA, Beranova M, Kada F, Seminara SB, Conn PM \& Kaiser UB 2003 Four naturally occurring mutations in the human GnRH receptor affect ligand binding and receptor function. Molecular and Cellular Endocrinology 205 51-64. (doi:10.1016/S03037207(03)00201-6)

Begriche K, Marston OJ, Rossi J, Burke LK, McDonald P, Heisler LK \& Butler AA 2012 Melanocortin-3 receptors are involved in adaptation to restricted feeding. Genes, Brain, and Behavior 11 291-302. (doi:10.1111/ j.1601-183X.2012.00766.x)

Butler AA, Kesterson RA, Khong K, Cullen MJ, Pelleymounter MA, Dekoning J, Baetscher M \& Cone RD 2000 A unique metabolic syndrome causes obesity in the melanocortin-3 receptor-deficient mouse. Endocrinology 141 3518-3521. (doi:10.1210/endo.141.9.7791)

Calton MA, Ersoy BA, Zhang S, Kane JP, Malloy MJ, Pullinger CR, Bromberg Y, Pennacchio LA, Dent R, McPherson R et al. 2009 Association of functionally significant melanocortin- 4 but not melanocortin-3 receptor mutations with severe adult obesity in a large North American case-control study. Human Molecular Genetics 18 1140-1147. (doi:10.1093/hmg/ddn431)

Catania A, Gatti S, Colombo G \& Lipton JM 2004 Targeting melanocortin receptors as a novel strategy to control inflammation. Pharmacological Reviews 56 1-29. (doi:10.1124/pr.56.1.1)

Chai B, Li JY, Zhang W, Ammori JB \& Mulholland MW 2007 Melanocortin-3 receptor activates MAP kinase via PI3 kinase. Regulatory Peptides 139 115-121. (doi:10.1016/j.regpep.2006.11.003)

Chandramohan G, Durham N, Sinha S, Norris K \& Vaziri ND 2009 Role of $\gamma$ melanocyte-stimulating hormone-renal melanocortin 3 receptor system in blood pressure regulation in salt-resistant and salt-sensitive rats. Metabolism 58 1424-1429. (doi:10.1016/j.metabol.2009.04.022)

Chen C \& Okayama H 1987 High-efficiency transformation of mammalian cells by plasmid DNA. Molecular and Cellular Biology 7 2745-2752.

Chen AS, Marsh DJ, Trumbauer ME, Frazier EG, Guan XM, Yu H, Rosenblum CI, Vongs A, Feng Y, Cao L et al. 2000 Inactivation of the mouse melanocortin-3 receptor results in increased fat mass and reduced lean body mass. Nature Genetics 26 97-102. (doi:10.1038/ 79254)

Chhajlani V 1996 Distribution of cDNA for melanocortin receptor subtypes in human tissues. Biochemistry and Molecular Biology International 38 73-80.

Cone RD 1999 The central melanocortin system and energy homeostasis. Trends in Endocrinology and Metabolism 10 211-216. (doi:10.1016/ S1043-2760(99)00153-8)

Cunningham BC \& Wells JA 1989 High-resolution epitope mapping of hGH-receptor interactions by alanine-scanning mutagenesis. Science 244 1081-1085. (doi:10.1126/science.2471267)

Daniels D, Patten CS, Roth JD, Yee DK \& Fluharty SJ 2003 Melanocortin receptor signaling through mitogen-activated protein kinase in vitro and in rat hypothalamus. Brain Research 986 1-11. (doi:10.1016/ S0006-8993(03)03162-7)

Delos Santos NM, Gardner LA, White SW \& Bahouth SW 2006 Characterization of the residues in helix 8 of the human $\beta 1$-adrenergic receptor that are involved in coupling the receptor to $\mathrm{G}$ proteins. Journal of Biological Chemistry 281 12896-12907. (doi:10.1074/jbc. M508500200)

Ernst OP, Meyer CK, Marin EP, Henklein P, Fu WY, Sakmar TP \& Hofmann KP 2000 Mutation of the fourth cytoplasmic loop of rhodopsin affects binding of transducin and peptides derived from the carboxyl-terminal sequences of transducin ( and () subunits. Journal of Biological Chemistry 275 1937-1943. (doi:10.1074/jbc.275.3.1937)

Farooqi IS, Keogh JM, Yeo GS, Lank EJ, Cheetham T \& O’Rahilly S 2003 Clinical spectrum of obesity and mutations in the melanocortin

Published by Bioscientifica Ltd. 
4 receptor gene. New England Journal of Medicine 348 1085-1095. (doi:10.1056/NEJMoa022050)

Faussner A, Bauer A, Kalatskaya I, Schussler S, Seidl C, Proud D \& Jochum M 2005 The role of helix 8 and of the cytosolic C-termini in the internalization and signal transduction of B1 and B2 bradykinin receptors. FEBS Journal 272 129-140. (doi:10.1111/j.1432-1033.2004. 04390.x)

Feng $\mathrm{W} \&$ Song ZH 2001 Functional roles of the tyrosine within the $\mathrm{NP}(\mathrm{X})(\mathrm{n}) \mathrm{Y}$ motif and the cysteines in the C-terminal juxtamembrane region of the CB2 cannabinoid receptor. FEBS Letters 501 166-170. (doi:10.1016/S0014-5793(01)02642-4)

Fritze O, Filipek S, Kuksa V, Palczewski K, Hofmann KP \& Ernst OP 2003 Role of the conserved $\operatorname{NPxxY}(\mathrm{x}) 5,6 \mathrm{~F}$ motif in the rhodopsin ground state and during activation. PNAS 100 2290-2295. (doi:10.1073/pnas. 0435715100)

Gabilondo AM, Hegler J, Krasel C, Boivin-Jahns V, Hein L \& Lohse MJ 1997 A dileucine motif in the $\mathrm{C}$ terminus of the $\beta 2$-adrenergic receptor is involved in receptor internalization. PNAS 94 12285-12290. (doi:10.1073/pnas.94.23.12285)

Gantz I, Konda Y, Tashiro T, Shimoto Y, Miwa H, Munzert G, Watson SJ, DelValle J \& Yamada T 1993 Molecular cloning of a novel melanocortin receptor. Journal of Biological Chemistry 268 8246-8250.

Getting SJ, Christian HC, Lam CW, Gavins FN, Flower RJ, Schioth HB \& Perretti M 2003 Redundancy of a functional melanocortin 1 receptor in the anti-inflammatory actions of melanocortin peptides: studies in the recessive yellow (e/e) mouse suggest an important role for melanocortin 3 receptor. Journal of Immunology 170 3323-3330. (doi:10.4049/jimmunol.170.6.3323)

Getting SJ, Lam CW, Chen AS, Grieco P \& Perretti M 2006 Melanocortin 3 receptors control crystal-induced inflammation. FASEB Journal $\mathbf{2 0}$ 2234-2241. (doi:10.1096/fj.06-6339com)

Getting SJ, Riffo-Vasquez Y, Pitchford S, Kaneva M, Grieco P, Page CP, Perretti M \& Spina D 2008 A role for MC3R in modulating lung inflammation. Pulmonary Pharmacology \& Therapeutics 21 866-873. (doi:10.1016/j.pupt.2008.09.004)

He S \& Tao YX 2014 Defect in MAPK signaling as a cause for monogenic obesity caused by inactivating mutations in the melanocortin- 4 receptor gene. International Journal of Biological Sciences 10 1128-1137. (doi:10.7150/ijbs.10359)

Hinney A, Volckmar AL \& Knoll N 2013 Melanocortin-4 receptor in energy homeostasis and obesity pathogenesis. Progress in Molecular Biology and Translational Science 114 147-191. (doi:10.1016/B978-0-12-386933-3. 00005-4)

Ho G \& MacKenzie RG 1999 Functional characterization of mutations in melanocortin-4 receptor associated with human obesity. Journal of Biological Chemistry 274 35816-35822. (doi:10.1074/jbc.274.50.35816)

Huang H \& Tao YX 2012 Pleiotropic functions of the transmembrane domain 6 of human melanocortin-4 receptor. Journal of Molecular Endocrinology 49 237-248. (doi:10.1530/JME-12-0161)

Huang H \& Tao YX 2014 Functions of the DRY motif and intracellular loop 2 of human melanocortin 3 receptor. Journal of Molecular Endocrinology 53 319-330. (doi:10.1530/JME-14-0184)

Huszar D, Lynch CA, Fairchild-Huntress V, Dunmore JH, Fang Q, Berkemeier LR, Gu W, Kesterson RA, Boston BA, Cone RD et al. 1997 Targeted disruption of the melanocortin-4 receptor results in obesity in mice. Cell 88 131-141. (doi:10.1016/S0092-8674(00)81865-6)

Jegou S, Boutelet I \& Vaudry H 2000 Melanocortin-3 receptor mRNA expression in pro-opiomelanocortin neurones of the rat arcuate nucleus. Journal of Neuroendocrinology 12 501-505. (doi:10.1046/j.13652826.2000.00477.x)

Kobilka BK \& Deupi X 2007 Conformational complexity of G-proteincoupled receptors. Trends in Pharmacological Sciences 28 397-406. (doi:10.1016/j.tips.2007.06.003)

Kuwasako K, Kitamura K, Nagata S, Hikosaka T \& Kato J 2011 Structurefunction analysis of helix 8 of human calcitonin receptor-like receptor within the adrenomedullin 1 receptor. Peptides 32 144-149. (doi:10.1016/j.peptides.2010.10.005)

Lee YS, Poh LK \& Loke KY 2002 A novel melanocortin 3 receptor gene (MC3R) mutation associated with severe obesity. Journal of Clinical Endocrinology and Metabolism 87 1423-1426. (doi:10.1210/jcem.87.3.8461)

Lee YS, Poh LK, Kek BL \& Loke KY 2007 The role of melanocortin 3 receptor gene in childhood obesity. Diabetes 56 2622-2630. (doi:10.2337) db07-0225)

Lu ZL, Gallagher R, Sellar R, Coetsee M \& Millar RP 2005 Mutations remote from the human gonadotropin-releasing hormone (GnRH) receptorbinding sites specifically increase binding affinity for GnRH II but not GnRH I: evidence for ligand-selective, receptor-active conformations. Journal of Biological Chemistry 280 29796-29803. (doi:10.1074/jbc. M413520200)

Marin EP, Krishna AG, Zvyaga TA, Isele J, Siebert F \& Sakmar TP 2000 The amino terminus of the fourth cytoplasmic loop of rhodopsin modulates rhodopsin-transducin interaction. Journal of Biological Chemistry 275 1930-1936. (doi:10.1074/jbc.275.3.1930)

Mencarelli M, Walker GE, Maestrini S, Alberti L, Verti B, Brunani A, Petroni ML, Tagliaferri M, Liuzzi A \& Di Blasio AM 2008 Sporadic mutations in melanocortin receptor 3 in morbid obese individuals. European Journal of Human Genetics 16 581-586. (doi:10.1038/sj.ejhg.5202005)

Mioni C, Giuliani D, Cainazzo MM, Leone S, Bazzani C, Grieco P, Novellino E, Tomasi A, Bertolini A \& Guarini S 2003 Further evidence that melanocortins prevent myocardial reperfusion injury by activating melanocortin MC3 receptors. European Journal of Pharmacology $\mathbf{4 7 7}$ 227-234. (doi:10.1016/S0014-2999(03)02184-8)

Mo XL, Yang R \& Tao YX 2012 Functions of transmembrane domain 3 of human melanocortin-4 receptor. Journal of Molecular Endocrinology 49 221-235. (doi:10.1530/JME-12-0162)

Montero-Melendez T, Gobbetti T, Cooray SN, Jonassen TE \& Perretti M 2015 Biased agonism as a novel strategy to harness the proresolving properties of melanocortin receptors without eliciting melanogenic effects. Journal of Immunology 194 3381-3388. (doi:10.4049/jimmunol. 1402645)

Moore SA, Patel AS, Huang N, Lavin BC, Grammatopoulos TN, Andres RD \& Weyhenmeyer JA 2002 Effects of mutations in the highly conserved DRY motif on binding affinity, expression, and G-protein recruitment of the human angiotensin II type-2 receptor. Brain Research. Molecular Brain Research 109 161-167. (doi:10.1016/S0169-328X(02)00552-1)

Mustafi D \& Palczewski K 2009 Topology of class A G protein-coupled receptors: insights gained from crystal structures of rhodopsins, adrenergic and adenosine receptors. Molecular Pharmacology 75 1-12. (doi:10.1124/mol.108.051938)

Ni XP, Butler AA, Cone RD \& Humphreys MH 2006 Central receptors mediating the cardiovascular actions of melanocyte stimulating hormones. Journal of Hypertension 24 2239-2246. (doi:10.1097/01.hjh. 0000249702.49854.fa)

Nijenhuis WA, Oosterom J \& Adan RA 2001 AgRP(83-132) acts as an inverse agonist on the human melanocortin-4 receptor. Molecular Endocrinology 15 164-171. (doi:10.1210/mend.15.1.0578)

Pan Y, Wilson P \& Gitschier J 1994 The effect of eight V2 vasopressin receptor mutations on stimulation of adenylyl cyclase and binding to vasopressin. Journal of Biological Chemistry 269 31933-31937.

Park JH, Scheerer P, Hofmann KP, Choe HW \& Ernst OP 2008 Crystal structure of the ligand-free G-protein-coupled receptor opsin. Nature 454 183-187. (doi:10.1038/nature07063)

Prioleau C, Visiers I, Ebersole BJ, Weinstein H \& Sealfon SC 2002 Conserved helix 7 tyrosine acts as a multistate conformational switch in the 5 HT2C receptor. Identification of a novel "locked-on" phenotype and double revertant mutations. Journal of Biological Chemistry 277 36577-36584. (doi:10.1074/jbc.M206223200)

Rached M, Buronfosse A, Begeot M \& Penhoat A 2004 Inactivation and intracellular retention of the human I183N mutated melanocortin 3 
receptor associated with obesity. Biochimica et Biophysica Acta 1689 229-234. (doi:10.1016/j.bbadis.2004.03.009)

Renquist BJ, Lippert RN, Sebag JA, Ellacott KL \& Cone RD 2011 Physiological roles of the melanocortin MC3 receptor. European Journal of Pharmacology 660 13-20. (doi:10.1016/j.ejphar.2010.12.025)

Roselli-Rehfuss L, Mountjoy KG, Robbins LS, Mortrud MT, Low MJ, Tatro JB, Entwistle ML, Simerly RB \& Cone RD 1993 Identification of a receptor for (C) melanotropin and other proopiomelanocortin peptides in the hypothalamus and limbic system. PNAS 90 8856-8860. (doi:10.1073/ pnas.90.19.8856)

Rosenbaum DM, Rasmussen SG \& Kobilka BK 2009 The structure and function of G-protein-coupled receptors. Nature 459 356-363. (doi:10.1038/nature08144)

Roth CL, Ludwig M, Woelfle J, Fan ZC, Brumm H, Biebermann H \& Tao YX 2009 A novel melanocortin-4 receptor gene mutation in a female patient with severe childhood obesity. Endocrine 36 52-59. (doi:10.1007/s12020-009-9156-4)

Roubert P, Dubern B, Plas P, Lubrano-Berthelier C, Alihi R, Auger F, Deoliveira DB, Dong JZ, Basdevant A, Thurieau C et al. 2010 Novel pharmacological MC4R agonists can efficiently activate mutated MC4R from obese patient with impaired endogenous agonist response. Journal of Endocrinology 207 177-183. (doi:10.1677/JOE-09-0336)

Rovati GE, Capra V \& Neubig RR 2007 The highly conserved DRY motif of class A G protein-coupled receptors: beyond the ground state. Molecular Pharmacology 71 959-964. (doi:10.1124/mol.106.029470)

Sawyer TK, Sanfilippo PJ, Hruby VJ, Engel MH, Heward CB, Burnett JB \& Hadley ME 1980 4-Norleucine, 7-D-phenylalanine-〈-melanocytestimulating hormone: a highly potent <-melanotropin with ultralong biological activity. PNAS 77 5754-5758. (doi:10.1073/pnas. 77.10.5754)

Scheerer P, Park JH, Hildebrand PW, Kim YJ, Krauss N, Choe HW, Hofmann KP \& Ernst OP 2008 Crystal structure of opsin in its G-proteininteracting conformation. Nature 455 497-502. (doi:10.1038/ nature07330)

Schulein R, Hermosilla R, Oksche A, Dehe M, Wiesner B, Krause G \& Rosenthal W 1998 A dileucine sequence and an upstream glutamate residue in the intracellular carboxyl terminus of the vasopressin V2 receptor are essential for cell surface transport in COS.M6 cells. Molecular Pharmacology 54 525-535.

Stutzmann F, Tan K, Vatin V, Dina C, Jouret B, Tichet J, Balkau B, Potoczna N, Horber F, O'Rahilly S et al. 2008 Prevalence of melanocortin-4 receptor deficiency in Europeans and their age-dependent penetrance in multigenerational pedigrees. Diabetes $\mathbf{5 7}$ 2511-2518. (doi:10.2337/db08-0153)

Swift S, Leger AJ, Talavera J, Zhang L, Bohm A \& Kuliopulos A 2006 Role of the PAR1 receptor 8 th helix in signaling: the 7-8-1 receptor activation mechanism. Journal of Biological Chemistry 281 4109-4116. (doi:10.1074/jbc.M509525200)

Tao YX 2006 Inactivating mutations of G protein-coupled receptors and diseases: structure-function insights and therapeutic implications. Pharmacology \& Therapeutics 111 949-973. (doi:10.1016/j.pharmthera. 2006.02.008)

Tao YX 2007 Functional characterization of novel melanocortin-3 receptor mutations identified from obese subjects. Biochimica et Biophysica Acta 1772 1167-1174. (doi:10.1016/j.bbadis.2007.09.002)
Tao YX 2009 Mutations in melanocortin-4 receptor and human obesity. Progress in Molecular Biology and Translational Science 88 173-204. (doi:10.1016/S1877-1173(09)88006-X)

Tao YX 2010a The melanocortin-4 receptor: physiology, pharmacology, and pathophysiology. Endocrine Reviews 31 506-543. (doi:10.1210/ er.2009-0037)

Tao YX $2010 b$ Mutations in the melanocortin-3 receptor (MC3R) gene: Impact on human obesity or adiposity. Current Opinion in Investigational Drugs 11 1092-1096.

Tao YX 2014 Constitutive activity in melanocortin-4 receptor: Biased signaling of inverse agonists. Advances in Pharmacology 70 135-154. (doi:10.1016/B978-0-12-417197-8.00005-5)

Tao YX \& Segaloff DL 2003 Functional characterization of melanocortin-4 receptor mutations associated with childhood obesity. Endocrinology 144 4544-4551. (doi:10.1210/en.2003-0524)

Tao YX \& Segaloff DL 2004 Functional characterization of melanocortin-3 receptor variants identify a loss-of-function mutation involving an amino acid critical for $G$ protein-coupled receptor activation. Journal of Clinical Endocrinology and Metabolism 89 3936-3942. (doi:10.1210/ jc.2004-0367)

Tao YX \& Conn PM 2014 Chaperoning G protein-coupled receptors: from cell biology to therapeutics. Endocrine Reviews 35 602-647. (doi:10.1210/er.2013-1121)

Tao YX, Huang H, Wang ZQ, Yang F, Williams JN \& Nikiforovich GV 2010 Constitutive activity of neural melanocortin receptors. Methods in Enzymology 484 267-279. (doi:10.1016/B978-0-12-381298-8.00014-9)

Tetsuka M, Saito Y, Imai K, Doi H \& Maruyama K 2004 The basic residues in the membrane-proximal C-terminal tail of the rat melanin-concentrating hormone receptor 1 are required for receptor function. Endocrinology 145 3712-3723. (doi:10.1210/en.2003-1638)

VanLeeuwen D, Steffey ME, Donahue C, Ho G \& MacKenzie RG 2003 Cell surface expression of the melanocortin- 4 receptor is dependent on a C-terminal di-isoleucine sequence at codons 316/317. Journal of Biological Chemistry 278 15935-15940. (doi:10.1074/jbc.M211546200)

Versteeg DH, Van Bergen P, Adan RA \& De Wildt DJ 1998 Melanocortins and cardiovascular regulation. European Journal of Pharmacology 360 1-14. (doi:10.1016/S0014-2999(98)00615-3)

Wang ZQ \& Tao YX 2013 Functions of the third intracellular loop of the human melanocortin-3 receptor. Current Pharmaceutical Design 19 4831-4838. (doi:10.2174/1381612811319270005)

Wang SX, Fan ZC \& Tao YX 2008 Functions of acidic transmembrane residues in human melanocortin-3 receptor binding and activation. Biochemical Pharmacology 76 520-530. (doi:10.1016/j.bcp.2008.05.026)

Wess J, Nanavati S, Vogel Z \& Maggio R 1993 Functional role of proline and tryptophan residues highly conserved among $\mathrm{G}$ protein-coupled receptors studied by mutational analysis of the $\mathrm{m} 3$ muscarinic receptor. EMBO Journal 12 331-338.

Yang F \& Tao YX 2012 Functional characterization of nine novel naturally occurring human melanocortin-3 receptor mutations. Biochimica et Biophysica Acta 1822 1752-1761. (doi:10.1016/j.bbadis.2012.07.017)

Yang F, Huang H \& Tao YX 2015 Biased signaling in naturally occurring mutations in human melanocortin-3 receptor gene. International Journal of Biological Sciences 11 423-433. (doi:10.7150/ijbs.11032)

Zhang D, Gao ZG, Zhang K, Kiselev E, Crane S, Wang J, Paoletta S, Yi C, Ma L, Zhang W et al. 2015 Two disparate ligand-binding sites in the human P2Y receptor. Nature 520 317-321. (doi:10.1038/nature14287)

Received in final form 21 July 2015

Accepted 27 July 2015

Accepted Preprint published online 28 July 2015 http://jme.endocrinology-journals.org

DOI: 10.1530/JME-15-0116
(C) 2015 Society for Endocrinology Printed in Great Britain
Published by Bioscientifica Ltd 